\title{
CHRONIC URTICARIA ASSOCIATED WITH HIGH-RISK OCCUPATIONS
}

\author{
Mikryukova NV ${ }^{1 \otimes}$, Kalinina NM ${ }^{1,2}$
}

${ }_{1}^{1}$ Nikiforov Russian Center of Emergency and Radiation Medicine, EMERCOM of Russia, St. Petersburg, Russia

2 St. Petersburg Pavlov State Medical University, St. Petersburg, Russia

\begin{abstract}
In their line of duty, firefighters and rescuers are exposed to a combination of adverse factors, which necessitates monitoring their health. This review covers the most common variants of urticaria associated with high-risk occupations, such as cholinergic urticaria, food-induced anaphylaxis and exercise-induced urticaria, cold and stress-induced urticaria. The analysis includes the relevant research results published up to 2020; the discussion outlines the possible pathogenesis mechanisms of chronic urticaria
\end{abstract}

Keywords: urticaria, stress, substance $\mathrm{P}$, high-risk occupations, rescuers

Author contribution: Mikryukova NV — information collection, manuscript authoring; Kalinina NM — editing and reviewing

$\triangle$ Correspondence should be addressed: Natalya V. Mikryukova

Optikov, 54, St. Petersburg, 197345; natalya@mikryukov.info

Received: 18.02.2021 Accepted: 02.03.2021 Published online: 15.03.2021

DOI: $10.47183 /$ mes.2021.006

\section{ХРОНИЧЕСКАЯ КРАПИВНИЦА У ПРЕДСТАВИТЕЛЕЙ ПРОФЕССИЙ ВЫСОКОГО РИСКА}

Н. В. Микрюкова ${ }^{1}$, Н. М. Калинина ${ }^{1,2}$

${ }^{1}$ Всероссийский центр экстренной и радиационной медицины имени А. М. Никифорова, Санкт-Петербург, Россия

2 Первый Санкт-Петербургский государственный медицинский университет имени И. П. Павлова, Санкт-Петербург, Россия

Совокупность неблагоприятных факторов условий труда пожарных и спасателей требует контроля за состоянием их здоровья. В обзоре представлены варианты крапивниц, наиболее часто встречающиеся у представителей профессий высокого риска, такие как холинергическая крапивница, пищевая анафилаксия и крапивница, вызванная физической нагрузкой, холодовая, стрессиндуцированная крапивница. Сделан анализ опубликованных результатов исследований до 2020 г. и обсуждены возможные механизмы патогенеза хронической крапивницы.

Ключевые слова: крапивница, стресс, субстанция Р, профессии высокого риска, спасатели

Вклад авторов: Н. В. Микрюкова - сбор информации, написание текста; Н. М. Калинина - редактирование и рецензирование

$\triangle$ Для корреспонденции: Наталья Васильевна Микрюкова

ул. Оптиков, д. 54, г. Санкт-Петербург, 197345; natalya@mikryukov.info

Статья получена: 18.02.2021 Статья принята к печати: 02.03.2021 Опубликована онлайн: 15.03.2021

DOI: $10.47183 /$ mes.2021.006

The growing number of emergency situations and disasters necessitates increasing the headcount of first responders while making the health requirements for them more stringent. The measures taken to preserve health of the rescuers in the context of responding to emergency situations (ES) are especially important, since such measures ensure their maximum effectiveness in the line of duty. The combination of adverse factors rescuers are exposed to professionally substantiates the need for monitoring of their health [1].

Human factor (individual characteristics and capabilities, including those related to personality) and the level of physical fitness (the state of the cardiovascular and pulmonary systems) cause many problems in the work of the rescuers. There are also situations involving contact with highly toxic substances, e.g., in the context of disinfection in the pandemic. In addition to emergency response, firefighting, piloting and military professions are considered to be extreme. High-risk occupations are such that have the worker exposed to harmful production factors (chemical, excessive physical, biological), life-threatening and increasing the risk of development of somatic pathologies. Contributing to the psychological stress are the long periods of relative inactivity accompanied by anxiety, and the stress load associated with rescue operations, all of which find reflection in the rescuers' clinical and laboratory examination results. For example, firefighters have been shown to be at risk of depression and post-traumatic stress disorder [2].

Russian researchers have not paid due attention to the state of immune system of rescuers, which is why we analyzed the available data describing individuals from other countries whose working conditions are similar to those of the employees of the Russian Ministry of Emergency Situations (EMERCOM): police officers responding to emergencies and fires, as well as world-class athletes. The data on the state of their health are fragmentary; it is shaped by chronic stress, the influence of chemically active substances, increased or excessive physical exertion, lack of sleep, 24-hour shifts. In this connection, it was decided to use the data from these studies for comparison purposes, since understanding of the immunopathological mechanisms enables prevention, timely identification and elimination of the cause of pathology.

Respiratory pathology and cardiovascular diseases are the most common subjects of research targeting highrisk occupations. Only a small number of papers cover dermatological pathologies in rescuers. For example, in 2016 it was shown that young people performing high-risk work often have skin disease symptoms [3]. Various types of urticaria have been described along with dermatitis.

"Chronic urticaria" is a term describing a group of disorders characterized by itching blisters and/or angioedema persisting for more than 6 weeks. Worldwide, 1-3\% of the population suffers from this disease, with women developing it twice as often as men [4]. Chronic urticaria can be spontaneous, without obvious triggers, and induced, with triggers being physical and chemical. The physical triggers are pressure (urticaria with delayed pressure), radiation (solar urticaria), friction (symptomatic dermographism), temperature (cold and warm urticaria) and 
vibration (vibratory angioedema). The chemical triggers are water (aquagenic urticaria), sweat (cholinergic urticaria) and other chemical compounds (contact urticaria) [5]. The disorders that call for differential diagnosis are those that were historically considered urticaria and syndromes that include urticaria/ angioedema, such as urticaria pigmentosa (mastocytosis), urticaria vasculitis, bradykinin-mediated angioedema, exerciseinduced anaphylaxis and some autoinflammatory syndromes [4]. The symptoms of some of these disorders manifest in childhood, so it is unlikely that patients with such pathologies will choose the considered occupations in their adulthood. The disorders may also be divided by the causative factor, e.g., into pseudo-allergic and stress-induced urticaria.

There are no reliable data on the prevalence of most of chronic urticaria. Chronic induced urticaria affects $0.5 \%$ of the population, but up to $70 \%$ of patients experience systemic reactions, including severe anaphylaxis [5]. The literature has $4-11.2 \%$ of the population suffering from cholinergic urticaria, while a third of all induced urticaria cases are cold urticaria [6].

\section{Physical exercise-induced urticaria}

Cholinergic urticaria (CU) occurs when the body's temperature increases following physical exercise, a stressful situation, being in a stuffy room, taking a hot bath. It has characteristic clinical manifestations, but the exact pathogenetic mechanism is still not fully clear. There are four subtypes of $\mathrm{CU}$ distinguished: $\mathrm{CU}$ with occlusion of pores; CU with acquired generalized hypohidrosis; CU with sweat allergy; idiopathic CU [7].

To understand the mechanisms behind occurrence of $\mathrm{CU}$, some authors studied the role of hypersensitivity to the autologous sweat antigens in the chronic CU's pathogenesis $[8,9]$. In 2010, researchers conducted an experiment that allowed discovering that acetylcholine induces degranulation in a dose-dependent manner, which conditions disturbance of expression of cholinergic receptor muscarinic 3 (CHRM3). CHRM3 is not expressed in the area of anhidrosis, but its expression persists to a small extent in the hypohydrotic area. Histological analysis revealed an infiltrate of $\mathrm{CD}^{+}-$and CD8 ${ }^{+}-$T-cells around endocrine glands in the anhydrotic area. The authors suggested that in the hypohydrotic area of the skin, exercise induces release of acetylcholine, which is not completely captured by the receptors of sweat glands (as in normal sweating) and affects the neighboring mast cells (MC), which can produce histamine in response to acetylcholine, since MC in the hypohydrotic area express CHRM3 [10].

The subtypes of urticaria most commonly seen in athletes are acute forms caused by physical stimuli such as exercise, temperature, sunlight, water, or certain levels of external pressure. $\mathrm{CU}$ is the most common type of physical urticaria registered in athletes under 30 [11].

Unfortunately, in addition to skin rashes, a number of patients developed anaphylaxis and bronchial obstruction. In the first place, the aggravation was seen in young people who were actively practicing heavy physical exercise, e.g. military personnel [12].

Exercise-induced anaphylaxis is a specific life-threatening reaction that occurs very unpredictably in susceptible individuals with CU [13]. People whose jobs are considered extreme do not perform optimally against the background of severe hypotension, fainting, or laryngeal edema. Typically, such symptoms are effectively controlled with appropriate medications, which, however, often have side effects that are unacceptable in high-risk situations. The literature describes four cases of CU in US Air Force pilots [13].
Other authors resorted to differential diagnosing while examining individuals presenting dermatological and systemic symptoms post-exercise. In particular, they aimed to differentiate between $\mathrm{CU}$ and exercise-induced anaphylaxis. In both cases, the symptoms were triggered by MC degranulation with the release of vasoactive substances. The exerciseinduced anaphylaxis and CU were differentiated between relying on the urticaria morphology, anaphylaxis reproducibility, progression and response to passive warming. The diagnosis was made after a thorough history study and examination of the morphology of the lesions. Treatment for acute episodes of exercise-induced anaphylaxis included cessation of exercise, adrenaline and antihistamines. Further therapy required changes to or abstinence from exercise, prevention of co-factors and prophylactic use of drugs (antihistamines, MC stabilizers etc) [14].

There are recorded cases of food anaphylaxis and exercise-induced urticaria. This is a rare condition, which has postprandial exercise causing anaphylaxis. One of the reviews presents the definition, etiology and pathogenetic mechanisms underlying this disease [15]. The review reports a number of foods, including wheat, eggs, chicken, shrimp, shellfish, nuts, fruits and vegetables, that can trigger this pathology; it also declares that exercising after meals can stimulate the release of mediators (mast cell mediators) from IgE-dependent $\mathrm{MC}$, which leads to urticaria and anaphylaxis once a certain exercise level threshold has been exceeded. Also, it is reported that high-intensity physical loads are more likely to provoke an attack than low-intensity and low-frequency exercise. Several other factors, such as physical and mental stress, fatigue, dry air, inadequate sleep, runny nose, wet weather and low temperatures, aggravate anaphylaxis. Some researchers have stated that intense and prolonged exercise promotes the conversion of Th1 lymphocytes to Th2 lymphocytes, with an increase in the production of Th2 cytokines. However, the exact pathogenesis underlying exercise-induced anaphylaxis is unknown. It has been suggested that exercise lowers the MC degranulation threshold. Another study showed that exercise disrupts digestion, and eating food abundant in allergens leads to an increase in the concentration of allergenic proteins in blood and to IgE-mediated sensitization of MC. Continued consumption of allergenic food led to MC degranulation, release of histamine, development of urticaria, angioedema, decreased blood pressure and fainting [15].

There are some conditions that modulate the onset of anaphylaxis as concomitant or potentiating factors that trigger it even when the allergen is consumed in small doses. The most frequently described factors of this kind are physical exercise, alcohol, certain foods, nonsteroidal anti-inflammatory drugs (NSAIDs) and concomitant infectious diseases [16].

One study describes skin tests with food allergens, which suggests the assumption the disease has an lgE-mediated mechanism underlying it. However, regardless of the food taken, some patients were recorded to experience anaphylaxis intensified with additional exercise [17]

Another study reports registering various clinical symptoms in the course of examination of patients with chronic exerciseinduced urticaria [18]. Some patients developed only a periorbital angioedema; others had giant urticaria, wheezing and hypotension; yet another group of patients exhibited clear signs of CU. Those with cutaneous or subcutaneous manifestations only had normal plasma histamine levels. The complement component levels $(\mathrm{C} 3, \mathrm{C} 4)$ remained normal, regardless of the form of urticaria considered. The elevated plasma histamine levels were detected only against the background of systemic symptoms (hypotension etc) manifesting simultaneously [18]. 
In another study, some CU and anaphylaxis patients showed signs of activation of the alternative complement pathway, while other patients had $\mathrm{CU}$ at the outset and then saw it developing into angioedema and vascular collapse. Plasma histamine levels were elevated during anaphylaxis, but there was no evidence of complement activation [19].

Authors of study [20] have described the physical manifestations of two states closely resembling each other. The first is CU, that is, chronic urticaria caused by increased body temperature. The second is exercise-induced anaphylaxis. Anaphylaxis can be idiopathic, following a specific trigger (food, medication, or insect bite), or exercise-induced. Cholinergic urticaria is caused by exercise, increased body temperature, strong emotions, hot or spicy food, hot water shower. The disease is characterized by generalized erythema, urticaria (a blister of 2-4 mm surrounded by erythema) and pruritus. Many patients report tingling, pruritus, or burning of the skin before blistering. As the reaction progresses, the macula may coalesce to form large areas of erythema that become increasingly difficult to recognize as urticaria. The lesions can appear anywhere on the body, but usually they first manifest on the torso and the neck and then spread distally to the face and the limbs. In rare cases, the progression of urticaria includes systemic symptoms, such as hypotension, angioedema, and bronchospasm. Urticaria appears 6 minutes into a session of physical activity. The symptoms increase within 12-25 minutes. The pathogenesis was associated with elevated serum histamine levels during the attack. There was described a group of patients with type I allergy to their own sweat. Twenty patients underwent autologous sweat testing and showed an immediate cutaneous reaction. A subset of patients with CU symptoms had allergic urticaria, which manifested only with perspiration. Exercise-induced urticaria and anaphylaxis began 45 minutes into an exercise session. The major symptoms other than urticaria included bronchospasm, laryngospasm, and/or vascular collapse. Some other symptoms were sudden fatigue, feeling of fever, hot flushes, sudden pruritus, gastrointestinal upset, squeezed throat, voice changes, troubled breathing. In contrast to a CU situation, the size of the blister reached 10-15 mm. In the absence of control, urticaria, bronchospasm, and airway edema progressed to vascular collapse. The pathogenesis was conditioned by the sudden release of basophil and MC mediators, which was confirmed by the increased serum tryptase level. With time, patients developed exercise tolerance, i.e. the frequency of manifestations has decreased. It is explained by the fact that, over time, physical exercising lightens the leukocyte inflammatory response, slows the release of pro-inflammatory cytokines and dampens the regulation of expression of toll-like receptors 4 on the surface of immune cells. These are the mechanisms that reduced the systemic immune response to exercise [20].

Another work reports exercise-induced anaphylaxis accompanied by anaphylactic symptoms (cutaneous, respiratory, gastrointestinal and cardiovascular) after physical activity. Cofactors were identified in about a third of all such cases: food, temperature (warm or cold), drugs (especially NSAIDs). The researchers postulated some pathophysiological mechanisms, such as changes in gastrointestinal mucosa permeability (including growth thereof), changes in the level of tissue transglutaminase that enables lgE cross-linking, increased production of cytokines, blood redistribution during exercise that leads to alteration of the MC degranulation process, changes in acid-base balance and sensitization to wheat omega-5-gliadin (O5G) [21]. In 2020, the studies investigating $05 G$ allergy were published. Patients with idiopathic urticaria and anaphylaxis were diagnosed to be sensitive to O5G. In both groups, the most common cofactor were physical exercises, followed by alcohol and NSAIDs [22].

\section{Cold urticaria}

Cold urticaria is of no less interest. In the overall population, the prevalence of cold urticaria is $0.05 \%$ [23]. The key pathophysiological mechanism behind the onset of chronic induced urticaria is the activation of skin MC. It is assumed that the factor triggering the said activation in chronic induced urticaria cases is the formation of autoantigens under the influence of physical factors [24]. Early studies of cold urticaria showed local release of histamine following cold stimulation [25].

Cold urticaria is characterized by blisters and angioedema developing after exposure to cold. According to a retrospective analysis, the mean temperature threshold of cold urticaria patients was $13.7 \pm 6.0^{\circ} \mathrm{C}\left(4-26{ }^{\circ} \mathrm{C}\right)$ [26]. Anaphylaxis may develop when swimming in water. The list of atypical cold urticarias includes atypical acquired cold urticaria, delayed cold urticaria, cold dermographism, cold cholinergic urticaria, systemic atypical cold urticaria. The distinction is made between primary and secondary cold urticaria. The possible causes of secondary cold urticaria are systemic diseases, monoclonal (lgG) or mixed (lgG/lgM, IgG/lgA) cryoglobulinemia, viral and/or bacterial infections, parasitic invasions, vasculitis [27].

\section{Pseudoallergen-induced urticaria}

There is a relationship between chronic urticaria and pseudoallergens. Pseudoallergens are low molecular weight compounds that can bind to the $\mathrm{X} 2$ receptor bound to G-protein on the MC membrane and lower the threshold for other factors to fully activate the MC mediator release capacity. The small size of these molecules renders direct IgE binding impossible, and there is no evidence that they act as haptens. However, it was established that the level of intestinal mucosa permeability increases under the influence of pseudoallergens and, consequently, diets limiting the intake thereof [28].

\section{Stress-induced urticaria}

Nociceptor neurons use many of the same molecular threat recognition pathways as immune cells. Responding to danger, peripheral nervous system cooperates directly with immune system to form an integrated defense mechanism. In combination with the high rate of neuronal transduction, the dense network of nerves in sensory and autonomic fibers of peripheral tissues enables rapid local and systemic neurogenic modulation of the immunity. Peripheral neurons also play an important role in immune dysfunction in cases of autoimmune and allergic diseases [29].

Human skin $\mathrm{MC}$ are closely associated with sensory nerve endings that release neuropeptides following antidromic stimulation by physical or chemical factors and stress. Recently, it has been again proposed to focus on the role of substance $\mathrm{P}(\mathrm{SP})$ in the development of chronic urticaria [30]. $\mathrm{SP}$ is involved in the activation and degranulation of MC. In turn, MC mediators, histamine and tryptase, can activate sensory nerves, supporting the interaction between MC and sensory fibers in MC-induced skin inflammation. Current data has the biological activity of SP manifesting not only through the Neurokinin-1 receptor (NK-1), but also through the Massrelated G-protein coupled receptor member X2, or MRGPRX2, with the subsequent activation of MC. MRGPRX2 was found 
to be activated in the skin of severe chronic urticaria patients [31]. It has been noted that persisting stress and infectious processes in chronic urticaria patients can activate MC through activation of several neuropeptides and antimicrobial host defense proteins acting through MRGPRX2 [28].

Many authors confirm the involvement of SP in the pathogenesis of urticaria, since SP can cause pruritus and angioedema, degranulation of $\mathrm{MC}$ and basophils, and act as a $\mathrm{MC}$ sensitizer, i.e. increasing their sensitivity to various triggers [32]. Recent studies of urticaria patients have shown them to have significantly higher SP circulation levels, clearly dependent on the disease severity [33]. They also had a higher number of circulating SP-positive basophils [34]. SP has been shown to induce degranulation in basophils obtained from the chronic urticaria patients. Besides, SP may be involved in pseudo-allergic reactions and act as a histamine-releasing factor in patients with urticaria.

As early as in 2004, it was shown that cytosolic $\mathrm{Ca}^{2+}$ concentration triggers release of neuropeptides from the sensory nerve [35]. Cutaneous sensory nerves express MRGPR in addition to tension regulated $\mathrm{Ca}$ channels, the activation of which increases the concentration of cytosolic $\mathrm{Ca}^{2+}$. MRGPR are involved in histamine-independent pruritus pathways. Their activation on MC causes severe itching, which subsequently leads to the destruction of skin cells and progression of the inflammatory process therein [36].

In addition, cationic channels expressed on sensory nerve endings include some transient receptor potential (TRP) channels that are involved in the release of neuropeptides. Triggering them results in the $\mathrm{Ca}^{2+}$ influx and the release of neuropeptides, such as SP and calcitonin gene-related peptide (CGRP), followed by neurogenic inflammation. TRP-mediated $\mathrm{Ca}^{2+}$ influx in the skin can regulate the proinflammatory cytokine gene expression by influencing the immune cells in addition to the neuropeptide release. TRPV1 is also found in skin cells that function as pain sensors for chemical stimuli, including keratinocytes, MC, dendritic cells, sebocytes, dermal blood vessels, hair follicles, and sweat glands [27]. In endothelial and smooth muscle cells, TRPV1-mediated $\mathrm{Ca}^{2+}$ influx induces vasodilation by releasing nitric oxide (NO). At the same time, TRPA1 is a non-selective $\mathrm{Ca}^{2+}$ channel that responds to cold sensations $\left(<17^{\circ} \mathrm{C}\right)$, unlike TRPV1. TRPA1 is localized in about 60-75\% of sensory C-fibers, which are also TRPV1-positive. Topical application of cinnamaldehyde (TRPA1 agonist) in human skin aggravates itching significantly, suggesting that TRPA1 plays a central part in the mechanism of pruritus [37]. The studies have investigated the role of TRPA1 in chronic skin inflammation. It is believed that TRP channels, especially TRPA1, act as a "gatekeeper" that mediates the transition of cytokine skin inflammation into the sensory nerve activation [38].

Much attention has been paid to the connection between urticaria and a high prevalence of depression, anxiety, and poor sleep quality. A TatTS study confirmed higher levels of depression and anxiety in individuals with chronic urticaria [19]. It was shown that urticaria has a negative effect on the quality of life and working efficiency [36].

The expression of the serotonin transporter protein (SERT) in the skin of chronic spontaneous urticaria patients was studied for association with depression and anxiety. The research uncovered the role played by SERT in the pathophysiological processes of inflammatory skin diseases. Chronic urticaria patients had higher SERT expression levels than patients from the control group [39]. There is mounting evidence that ongoing stress prolongs and worsens the course of chronic urticaria.

$\mathrm{ACTH}$ and its releasing factor were shown to activate basophils in chronic urticaria patients [40]. It was established that NLRP-3 inflammation grows against the background of depression and stress, which proves a link between psychological factors and exacerbation of urticaria as a result of emotional stress [41].

Another study [42] demonstrated that stress and severity of the disease condition the growth of level of C-reactive protein, interleukin 18 and the significant drop of the level of basal cortisol. Thus, chronic stress can contribute to the formation of a vicious circle in the urticaria pathogenesis [42].

In this connection, it should be noted that stress, leading to the release of sensory nerve neuropeptides, can alter the behavior of Langerhans cells in the dermis and the immune system of the skin, directing the immune response towards certain T-helper cells. In particular, CGRP stimulates Th17 cells, promoting inflammation by recruiting $T$ cells and neutrophils [43].

Neuropeptides such as CGRP and VIP can activate dendritic cells to direct Th2-type immune response and suppress the Th1-type response by stimulating the production of certain cytokines and decreasing or increasing the migration of dendritic cells to the local lymph nodes [44, 45].

Considering that signaling molecules released from the peripheral sensory nerve fibers regulate not only the lumen of small blood vessels but also chemotaxis of the immune cells, their return to original state, maturation and activation, it becomes clear that neuroimmune interactions are much more complex [29].

\section{Features of immune inflammation in rescuers and firefighters}

The intensity of work of professional rescuers and the duration of their employment contribute to the development of dysfunctions of organs and systems. According to the somatic pathology laboratory diagnosing guidelines for rescuers and firefighters, common for immunological indicators are the increase in the relative and absolute number of cells with CD25, HLAll, CD95 markers, the IL1 $\beta$ spontaneous production level, an increase of the absolute number of lymphocytes, T-cells and T-helpers, a shift of the immune response towards Th2. Spontaneous production of TNF, IL1 $\beta$ is higher than the reference values, which contributes to the formation of chronic inflammation in the absence of an infectious agent. Progressive increase in the ultimate level of immunoglobulin $\mathrm{E}$, which depends on the duration of active service, shows that rescuers grow sensitive to the inhaled and contact allergens [1].

Studying systemic inflammation in firefighters, researchers revealed that blood serum concentrations of IL8, VEGF and TNF $\alpha$ are significantly higher after participating in fire extinguishing than during rest periods [46]. After exposure to smoke, the levels of circulating cytokines were higher than usual, which stimulated bone marrow [47] and initiated a systemic inflammatory response to smoke inhalation. IL8, being a potent bone marrow stimulant, promoted the migration of neutrophils into the lung tissue [48], which intensified and prolonged neutrophilic inflammation in the bronchi and maintained systemic inflammation related to smoke inhalation.

\section{Conclusion}

This literature review presents the available data on the mechanisms of occurrence of chronic urticaria, which are most common in high-risk occupations. The formation of chronic inflammation in the absence of an infectious agent is beyond doubt, and the search for informative biomarkers continues. There is no doubt about the role of SP in the development of 
inflammatory process. However, further research is required to clarify its significance. Understanding the pathogenetic mechanisms of immune inflammation will improve the diagnosing of these conditions and optimize the related prevention measures.

\section{References}

1. Aleksanin SS, redaktor. Laboratornaja diagnostika somaticheskoj patologii u spasatelej, sotrudnikov federal'noj protivopozharnoj sluzhby Gosudarstvenoj protivopozharnoj sluzhby MChS Rossil i uchastnikov likvidacii radiacionnyh avarij (metodicheskie rekomendacii), SPb.: VCJeRM im. A. M. Nikiforova MChS Rosiii, 2015; 66 s. Russian.

2. Guidotti TL, Clough TL, Occupational Health Concerns of Firefighting. Annu Rev Public Health. 1992; 13: 151-171.

3. Aktas E, Esin MN. Skin disease symptoms and related risk factors among young workers in high-risk jobs. Contact Dermatitis. 2016; 75 (2): 96-105. PubMed PMID: 27271527.

4. Zuberbier T, Aberer W, Asero R., Abdul Latiff A. H., Baker D, et al. The EAACI/GALEN/EDFNAO guideline for the definition and management of urticaria. Allergy. 2018; 73 (7): 1393-414

5. Martinez-Escala M, Curto-Barredo L, Carnero L, Pujol RM, Gimenez-Arnau AM. Temperature thresholds in assessment of the clinical course of acquired cold contact urticaria: a prospective observational one-year study. Acta Derm Venereol. 2015; 95 (3): 278-82.

6. Maurer M, Hawro T, Krause K, Magerl M, Metz M, Siebenhaar F et al. Diagnosis and treatment of chronic inducible urticaria. Allergy. 2019; 74 (12): 2550-3

7. Nakamizo S, Kurosawa M, Sawada $Y$, Tokura $Y$, Miyachi $Y$, Kabashima K. A Case of Cholinergic Urticaria Associated With Acquired Generalized Hypohidrosis and Reduced Acetylcholine Receptors: Cause and Effect? Clin Exp Dermatol. 2011; 36 (5): 559-60.

8. Bito T, Sawada Yu, Tokura Y. Pathogenesis of cholinergic urticaria in relation to sweating. Allergology International. 2012; 61: 539-544.

9. Stephansson E, Koskimies S, Lokki ML. Exercise-induced Urticaria and Anaphylaxis. Acta Derm Venereol. 1991; 71 (2): 138-42.

10. Sawada Y, NakamuraM, Bito T, Fukamachi S, Kabashima R Sugita K, et al. Cholinergic urticaria: studies on the muscarinic cholinergic receptor M3 in anhidrotic and hypohidrotic skin. J Invest Dermatol. 2010; 130: 2683-6.

11. Tlougan BE, Mancini AJ, Mandell JA, Cohen DE, Sanchez MR. Skin conditions in figure skaters, ice-hockey players and speed skaters: part II - cold-induced, infectious and inflammatory dermatoses. Sports Med. 2011; 41 (11): 967-84.

12. Handfield KS, Dolan CK, Kaplan M, Cholinergic UrticariaWith Anaphylaxis: Hazardous Duty of a Deployed US Marine. Cutis. 2015; 95 (4): 241-3.

13. Whinnery JE, Anderson GK. Environmentally Induced Cholinergic Urticaria and Anaphylaxis. Aviat Space Environ Med. 1983; 54 (6): 551-3.

14. Hosey RG, Carek PJ, Goo A. Exercise-induced Anaphylaxis and Urticaria. Am Fam Physician. 2001; 64 (8): 1367-72.

15. Kim ChW, Figueroa A, Park ChH, Kwak YS, Kim KB, Seo DY, et al. Combined effects of food and exercise on anaphylaxis. Nutr Res Pract. 2013; 7 (5): 347-51.

16. Zogaj D, Ibranji A, Hoxha M. Exercise-induced Anaphylaxis: the Role of Cofactors. Mater Sociomed. 2014; 26 (6): 401-4.

17. Romano A, Di Fonso M, Giuffreda F, Papa G, Artesani MC, Viola M, et al. Food-dependent exercise-induced anaphylaxis: clinical and laboratory findings in 54 subjects. Int Arch Allergy Immunol. 2001; 125: $264-72$

18. Lewis J, Lieberman P, Treadwell G, Erffmeyer J. Exercise-induced Urticaria, Angioedema and Anaphylactoid Episodes. J Allergy Clinlmmunol. 1981; 68 (6): 432-37.

19. Tat TS. Higher levels of depression and anxiety in patients with chronic urticaria. Med SciMonit. 2019; 25: 115-20.

20. Montgomery SL, Cholinergic Urticaria and Exercise-Induced Anaphylaxis. Curr Sports Med Rep. 2015; 14 (1): 61-63.

21. Pravettoni V, Incorvaia C. Diagnosis of Exercise-Induced
Anaphylaxis: Current Insights. J Asthma Allergy. 2016; 9: 191-98.

22. Li Ph H, Thomas I, Wong JCh, Rutkowski K, Lau C. Differences in omega-5-gliadin Allergy: East Versus West. Asia Pac Allergy. 2020; 10 (1), 5

23. Siebenhaar F, Weller K, Mlynek A, Magerl M, Altrichter S, Viera Dos Santos R, et al. Acquired cold urticaria: clinical picture and update on diagnosis and treatment. Clin Exp Dermatol. 2007; 32 (3): 241-5.

24. Borzova EYu. Diagnostika hronicheskih inducirovannyh krapivnic. Rossijskij allergologicheskij zhurnal. 2019; 16 (2): 5-13.

25. Andersson T, Wardell $\mathrm{K}$, Anderson $\mathrm{C}$. Human in vivo cutaneous microdialysis: estimation of histamine release in cold urticaria. Acta Derm Venereol. 1995; 75 (5): 343-7.

26. Magerl M, Altrichter S, Borzova E, Giménez-Arnau A, Grattan C. EH, Lawlor $F$, et al. The definition, diagnostic testing, and management of chronic inducible urticarias — The EAACI/GA2LEN/EDF/UNEV consensus recommendations 2016 update and revision. Allergy. 2016; 71 (6): 780-802. DOI: 10.1111/all.12884.

27. Stander S, Moormann C, Schumacher M, Buddenkotte J, Artuc M, Shpacovitch V, et al. Expression of vanilloid receptor subtype 1 in cutaneous sensory nerve fibers, mast cells, and epithelial cells of appendage structures. Experimental dermatology. 2004; 13 (3): 129-39.

28. Bansal CJ, Bansal AS. Stress, pseudoallergens, autoimmunity, infection and inflammation in chronic spontaneous urticaria. Allergy Asthma Clin Immunol. 2019; 15: 56. PubMed PMID: 31528163.

29. Choi JE, Di Nardo A. Skin neurogenic inflammation. Seminlmmunopathol. 2018; 40 (3): 249-59.

30. Vena GA, Cassano N, Leo ED, Calogiuri GF, Nettis E. Focus on the role of substance $P$ in chronic urticaria. Clinical and Molecular Allergy. 2018; 16: 24.

31. Fujisawa D, Kashiwakura J, Kita H, Kikukawa Y, Fujitani Y, SasakiSakamoto T, et al. Expression of Mas-related gene X2 on mast cells is upregulated in the skin of patients with severe chronic urticaria. J Allergy Clinlmmunol. 2014; 134: 622-33.

32. Kocatürk E, Maurer M, Metz M, Grattan C. Looking forward to new targeted treatments for chronic spontaneous urticaria. Clin Transl Allergy. 2017; $7: 1$.

33. Metz M, Krull C, Hawro T, Saluja R, Groffik A, Stanger C, et al, Substance $P$ is upregulated in the serum of patients with chronic spontaneous urticaria. J Invest Dermatol. 2014; 134: 2833-6.

34. Zheng W, Wang J, Zhu W, Xu C, He S. Upregulated expression of substance $P$ in basophils of the patients with chronic spontaneous urticaria: induction of histamine release and basophil accumulation by substance P. Cell Biol Toxicol. 2016; 32: 217-28.

35. Jans $R$, Sartor $M$, Jadot $M$, Poumay $Y$. Calcium entry into keratinocytes induces exocytosis of lysosomes. Archives of dermatological research. 2004; 296 (1): 30-41.

36. Vietri J, Turner SJ, Tian H, Isherwood G, Balp MM, Gabriel S. Effect of chronic urticaria on US patients: analysis of the National Health and Wellness Survey. Ann Allergy Asthma Immunol. 2015; 115 (4): 306-11.

37. Hojland CR, Andersen HH, Poulsen JN, Arendt-Nielsen L, Gazerani P. A human surrogate model of itch utilizing the TRPA1 agonist trans-cinnamaldehyde. ActaDermatoVenereologica. 2015; 95 (7): 798-803.

38. Gouin O, L'Herondelle K, Lebonvallet N, Le Gall-lanotto C, Sakka M, Buhe V, et al. TRPV1 and TRPA1 in cutaneous neurogenic and chronic inflammation: pro-inflammatory response induced by their activation and their sensitization. Protein \& Cell. 2017; 8 (9): 644-61.

39. Zabolinejad N, Molkara S, Bakhshodeh B, Ghaffari-Nazari H, Khoshkhui M. The Expression of Serotonin Transporter Protein in the Skin of Patients With Chronic Spontaneous Urticaria and Its Relation With Depression and Anxiety. Arch Dermatol Res. 2019; 
311 (10): 825-31.

40. Dyke SM, Carey BS, Kaminski ER. Effect of stress on basophil function in chronic idiopathic urticaria. ClinExp Allergy. 2008; 38 (1): 86-92.

41. Kaufmann FN, Costa AP, Ghisleni G, Diaz AP, Rodrigues ALS, Peluffo $\mathrm{H}$, et al. NLRP3 inflammasome-driven pathways in depression: clinical and preclinical findings. Brain Behav Immun. 2017; 64: 367-83.

42. Varghese R, Hui-Chan CWY, Bhatt T. Reduced Cognitive-Motor Interference on Voluntary Balance Control in Older Tai Chi Practitioners, J GeriatrPhysTher. Oct-Dec 2016; 39 (4): 190-9.

43. Ding W, Stohl LL, Xu L, Zhou XK, Manni M, Wagner JA, et al Calcitonin gene-related peptide-exposed endothelial cells bias antigen presentation to CD4+ T cells toward a Th17 response. $J$ Immunol. 2016; 196 (5): 2181-94.

44. Mikami N, et al. Calcitonin gene-related peptide is an important regulator of cutaneous immunity: effect on dendritic cell and T cell functions. J Immunol. 2011; 186: 6886-93.

45. Jimeno R, et al. Effect of VIP on the balance between cytokines and master regulators of activated helper T cells. Immunol Cell Biol. 2011; 90: 178-86.

46. Gianniou N, Giannakopoulou C, Dima E, Kardara M, Katsaounou $P$, Tsakatikas A, et al. Acute Effects of Smoke Exposure on Airway and Systemic Inflammation in Forest Firefighters. J Asthma Allergy. 2018; 11: 81-88.

47. Goto Y, Ishii H, Hogg JC, Shin C-H, Yatera K, Vincent R, et al. Particulate Matter Air Pollution Stimulates Monocyte Release from the Bone Marrow. American Journal of Respiratory and Critical Care Medicine. 2004; 170 (8): 891-7.

48. Terashima T, English D, Hogg JC, van Eeden SF. Release of polymorphonuclear leukocytes from the bone marrow by interleukin-8. Blood. 1998; 92 (3): 1062-9.

\section{Литература}

1. Алексанин С. С., редактор. Лабораторная диагностика соматической патологии у спасателей, сотрудников федеральной противопожарной службы Государственой противопожарной службы МЧС России и участников ликвидации радиационных аварий (методические рекомендации), СПб.: ВЦЭРМ им. А. М. Никифорова МЧС Росиии, 2015; 66 с.

2. Guidotti TL, Clough TL, Occupational Health Concerns of Firefighting. Annu Rev Public Health. 1992; 13: 151-171.

3. Aktas E, Esin MN. Skin disease symptoms and related risk factors among young workers in high-risk jobs. Contact Dermatitis. 2016; 75 (2): 96-105. PubMed PMID: 27271527.

4. Zuberbier T, Aberer W, Asero R., Abdul Latiff A. H., Baker D, et al. The EAACI/GALEN/EDF/WAO guideline for the definition and management of urticaria. Allergy. 2018; 73 (7): 1393-414.

5. Martinez-Escala M, Curto-Barredo L, Carnero L, Pujol RM, Gimenez-Arnau AM. Temperature thresholds in assessment of the clinical course of acquired cold contact urticaria: a prospective observational one-year study. Acta Derm Venereol. 2015; 95 (3): 278-82.

6. Maurer M, Hawro T, Krause K, Magerl M, Metz M, Siebenhaar F et al. Diagnosis and treatment of chronic inducible urticaria. Allergy. 2019; 74 (12): 2550-3.

7. Nakamizo S, Kurosawa M, Sawada Y, Tokura Y, Miyachi Y, Kabashima K. A Case of Cholinergic Urticaria Associated With Acquired Generalized Hypohidrosis and Reduced Acetylcholine Receptors: Cause and Effect? Clin Exp Dermatol. 2011; 36 (5): 559-60.

8. Bito T, Sawada Yu, Tokura Y. Pathogenesis of cholinergic urticaria in relation to sweating. Allergology International. 2012; 61: 539-544.

9. Stephansson E, Koskimies S, Lokki ML. Exercise-induced Urticaria and Anaphylaxis. Acta Derm Venereol. 1991; 71 (2): 138-42.

10. Sawada Y, NakamuraM, Bito T, Fukamachi S, Kabashima R, Sugita K, et al. Cholinergic urticaria: studies on the muscarinic cholinergic receptor M3 in anhidrotic and hypohidrotic skin. $J$ Invest Dermatol. 2010; 130: 2683-6.

11. Tlougan BE, Mancini AJ, Mandell JA, Cohen DE, Sanchez MR. Skin conditions in figure skaters, ice-hockey players and speed skaters: part II - cold-induced, infectious and inflammatory dermatoses. Sports Med. 2011; 41 (11): 967-84.

12. Handfield KS, Dolan CK, Kaplan M, Cholinergic UrticariaWith Anaphylaxis: Hazardous Duty of a Deployed US Marine. Cutis. 2015; 95 (4): 241-3.

13. Whinnery JE, Anderson GK. Environmentally Induced Cholinergic Urticaria and Anaphylaxis. Aviat Space Environ Med. 1983; 54 (6): 551-3.

14. Hosey RG, Carek PJ, Goo A. Exercise-induced Anaphylaxis and Urticaria. Am Fam Physician. 2001; 64 (8): 1367-72.

15. Kim ChW, Figueroa A, Park ChH, Kwak YS, Kim KB, Seo DY, et al. Combined effects of food and exercise on anaphylaxis. Nutr Res Pract. 2013; 7 (5): 347-51.

16. Zogaj D, Ibranji A, Hoxha M. Exercise-induced Anaphylaxis: the Role of Cofactors. Mater Sociomed. 2014; 26 (6): 401-4.

17. Romano A, Di Fonso M, Giuffreda F, Papa G, Artesani MC, Viola M, et al. Food-dependent exercise-induced anaphylaxis: clinical and laboratory findings in 54 subjects. Int Arch Allergy Immunol. 2001; 125: 264-72.

18. Lewis J, Lieberman P, Treadwell G, Erffmeyer J. Exercise-induced Urticaria, Angioedema and Anaphylactoid Episodes. J Allergy Clinlmmunol. 1981; 68 (6): 432-37.

19. Tat TS. Higher levels of depression and anxiety in patients with chronic urticaria. Med SciMonit. 2019; 25: 115-20.

20. Montgomery SL, Cholinergic Urticaria and Exercise-Induced Anaphylaxis. Curr Sports Med Rep. 2015; 14 (1): 61-63.

21. Pravettoni V, Incorvaia C. Diagnosis of Exercise-Induced Anaphylaxis: Current Insights. J Asthma Allergy. 2016; 9: 191-98.

22. Li Ph H, Thomas I, Wong JCh, Rutkowski K, Lau C. Differences in omega-5-gliadin Allergy: East Versus West, Asia Pac Allergy. 2020; 10 (1): 5

23. Siebenhaar F, Weller K, Mlynek A, Magerl M, Altrichter S, Viera Dos Santos R, et al. Acquired cold urticaria: clinical picture and update on diagnosis and treatment. Clin Exp Dermatol. 2007; 32 (3): $241-5$.

24. Борзова Е. Ю. Диагностика хронических индуцированных крапивниц. Российский аллергологический журнал. 2019; 16 (2): 5-13.

25. Andersson T, Wardell $\mathrm{K}$, Anderson C. Human in vivo cutaneous microdialysis: estimation of histamine release in cold urticaria. Acta Derm Venereol. 1995; 75 (5): 343-7.

26. Magerl M, Altrichter S, Borzova E, Giménez-Arnau A, Grattan C. EH, Lawlor $F$, et al. The definition, diagnostic testing, and management of chronic inducible urticarias - The EAACI/GA2LEN/EDF/UNEV consensus recommendations 2016 update and revision. Allergy. 2016; 71 (6): 780-802. DOI: 10.1111/all.12884.

27. Stander S, Moormann C, Schumacher M, Buddenkotte J, Artuc M, Shpacovitch V, et al. Expression of vanilloid receptor subtype 1 in cutaneous sensory nerve fibers, mast cells, and epithelial cells of appendage structures. Experimental dermatology. 2004; 13 (3): 129-39.

28. Bansal CJ, Bansal AS. Stress, pseudoallergens, autoimmunity, infection and inflammation in chronic spontaneous urticaria. Allergy Asthma Clin Immunol. 2019; 15: 56. PubMed PMID: 31528163.

29. Choi JE, Di Nardo A. Skin neurogenic inflammation. Seminlmmunopathol. 2018; 40 (3): 249-59.

30. Vena GA, Cassano N, Leo ED, Calogiuri GF, Nettis E. Focus on the role of substance $P$ in chronic urticaria. Clinical and Molecular Allergy. 2018; 16: 24

31. Fujisawa D, Kashiwakura J, Kita H, Kikukawa Y, Fujitani Y, SasakiSakamoto T, et al. Expression of Mas-related gene X2 on mast cells is upregulated in the skin of patients with severe chronic urticaria. J Allergy ClinImmunol. 2014; 134: 622-33.

32. Kocatürk E, Maurer M, Metz M, Grattan C. Looking forward to 
new targeted treatments for chronic spontaneous urticaria. Clin Transl Allergy. 2017; 7: 1

33. Metz M, Krull C, Hawro T, Saluja R, Groffik A, Stanger C, et al Substance $\mathrm{P}$ is upregulated in the serum of patients with chronic spontaneous urticaria. J Invest Dermatol. 2014; 134: 2833-6.

34. Zheng W, Wang J, Zhu W, Xu C, He S. Upregulated expression of substance $\mathrm{P}$ in basophils of the patients with chronic spontaneous urticaria: induction of histamine release and basophil accumulation by substance P. Cell Biol Toxicol. 2016; 32: 217-28.

35. Jans $R$, Sartor $M$, Jadot $M$, Poumay $Y$. Calcium entry into keratinocytes induces exocytosis of lysosomes. Archives of dermatological research. 2004; 296 (1): 30-41.

36. Vietri J, Turner SJ, Tian H, Isherwood G, Balp MM, Gabriel S. Effect of chronic urticaria on US patients: analysis of the National Health and Wellness Survey. Ann Allergy Asthma Immunol. 2015; 115 (4): 306-11.

37. Hojland $\mathrm{CR}$, Andersen $\mathrm{HH}$, Poulsen JN, Arendt-Nielsen L, Gazerani P. A human surrogate model of itch utilizing the TRPA1 agonist trans-cinnamaldehyde. ActaDermatoVenereologica. 2015; 95 (7): 798-803.

38. Gouin O, L'Herondelle K, Lebonvallet N, Le Gall-lanotto C, Sakka M, Buhe V, et al. TRPV1 and TRPA1 in cutaneous neurogenic and chronic inflammation: pro-inflammatory response induced by their activation and their sensitization. Protein \& Cell. 2017; 8 (9): 644-61.

39. Zabolinejad N, Molkara S, Bakhshodeh B, Ghaffari-Nazari H, Khoshkhui M. The Expression of Serotonin Transporter Protein in the Skin of Patients With Chronic Spontaneous Urticaria and Its Relation With Depression and Anxiety. Arch Dermatol Res. 2019; 311 (10): 825-31.

40. Dyke SM, Carey BS, Kaminski ER. Effect of stress on basophil function in chronic idiopathic urticaria. ClinExp Allergy. 2008; 38 (1): 86-92.

41. Kaufmann FN, Costa AP, Ghisleni G, Diaz AP, Rodrigues ALS, Peluffo $\mathrm{H}$, et al. NLRP3 inflammasome-driven pathways in depression: clinical and preclinical findings. Brain Behav Immun. 2017; 64: 367-83.

42. Varghese R, Hui-Chan CWY, Bhatt T. Reduced Cognitive-Motor Interference on Voluntary Balance Control in Older Tai Chi Practitioners, J GeriatrPhysTher. Oct-Dec 2016; 39 (4): 190-9.

43. Ding $W$, Stohl LL, Xu L, Zhou XK, Manni M, Wagner JA, et al Calcitonin gene-related peptide-exposed endothelial cells bias antigen presentation to CD4+ T cells toward a Th17 response. J Immunol. 2016; 196 (5): 2181-94.

44. Mikami N, et al. Calcitonin gene-related peptide is an important regulator of cutaneous immunity: effect on dendritic cell and T cell functions. J Immunol. 2011; 186: 6886-93.

45. Jimeno R, et al. Effect of VIP on the balance between cytokines and master regulators of activated helper T cells. Immunol Cell Biol. 2011; 90: 178-86.

46. Gianniou N, Giannakopoulou C, Dima E, Kardara M, Katsaounou P, Tsakatikas A, et al. Acute Effects of Smoke Exposure on Airway and Systemic Inflammation in Forest Firefighters. J Asthma Allergy. 2018; 11: 81-88.

47. Goto Y, Ishii H, Hogg JC, Shih $\mathrm{C}-\mathrm{H}$, Yatera K, Vincent R, et al. Particulate Matter Air Pollution Stimulates Monocyte Release from the Bone Marrow. American Journal of Respiratory and Critical Care Medicine. 2004; 170 (8): 891-7.

48. Terashima T, English D, Hogg JC, van Eeden SF. Release of polymorphonuclear leukocytes from the bone marrow by interleukin-8. Blood. 1998; 92 (3): 1062-9. 